\title{
A Propensity Score Matching Analysis Showed the Significant Association of Anterior Uveitis With Radiographic Progression in Axial Spondyloarthritis
}

\author{
Min-Chan Park, M.D., Ph.D. \\ Division of Rheumatology, Department of Internal Medicine, Gangnam Severance Hospital, Yonsei University College of Medicine, Seoul, Korea
}

Axial spondyloarthritis (axSpA) covers a broad spectrum of patients presenting with inflammation of the sacroiliac joint and spine, as well as various extra-articular manifestations. Ankylosing spondylitis (AS) is the prototypical SpA disease in which inflammatory responses lead to new bone formation, such as ankylosis of the sacroiliac joints, syndesmophytes and even fusion of the spine. Pharmacotherapy for axSpA has significantly broadened beyond non-steroidal anti-inflammatory drugs over the past two decades with the availability of biologic agents, including tumor necrosis factor inhibitors and interleukin-17 inhibitors [1]. Although these therapies have been shown to be very effective in controlling inflammatory activity, relieving pain and reducing functional impairment in many patients, evidence is still lacking regarding whether they can halt or slow the spinal damages in AS.

AS is a slowly progressive disease, and longitudinal assessment of structural damages with extended follow-up is needed to monitor the progression of spinal ankylosis [2]. Currently, conventional radiography is the gold standard for the assessment of the extent and severity of spinal disease caused by axSpA [3]. For quantification of spinal damage, several scoring systems have been developed and, among them, the progression of spinal ankylosis is best studied by the modified Stoke Ankylosing Spondylitis Spinal Score (mSASSS) [4] as it has been shown to be superior in terms of reliability and sensitivity to change. However, syndesmophytosis is a fairly slow process requiring a follow-up of at least two years before change can be reliably detected and not all spine regions are included in the evaluation. Moreover, several factors may play a role in the occurrence and progression of spinal damage. Recognizing these factors, understanding their strength of association and controlling them are required to understand the process of spinal fusion fully.

Available data suggest that inflammation is essential for the development of subsequent spinal damage. Radiographic spinal progression is positively associated with elevated C-reactive protein (CRP), active inflammation on magnetic resonance imaging, and the Ankylosing Spondylitis Disease Activity Score (ASDAS) [5,6]. Other contributors, including male sex, smoking, HLA-B27-positivity, and initial presence of syndesmophytes, have also been found to be significantly associated with radiographic progression of AS [6-9].

In the recent issue of Journal of Rheumatic Diseases, Kim et al. [10] investigated the association between acute anterior uveitis (AAU) and radiographic progression of axSpA using a propensity score (PS) matching analysis. Their study enrolled 253 patients with axSpA classified based on the Assessment of Spondyloarthritis International Society classification criteria and examined various clinical parameters, including age, sex, smoking status, HLA-B27 status, history of extra-articular manifestations (uveitis, psoriasis, inflammatory bowel disease, peripheral arthritis, and enthesitis), ASDAS-CRP, as well as mSASSS. In their results, the authors found that patients with AAU had the lower rate of mSASSS increase, defined as worsening of the mSASSS by more than two units over

Received : December 9, 2019, Revised : December 9, 2019, Accepted : December 10, 2019

Corresponding to : Min-Chan Park (iD http://orcid.org/0000-0003-1189-7637

Division of Rheumatology, Department of Internal Medicine, Gangnam Severance Hospital, Yonsei University College of Medicine, 211 Eonju-ro, Gangnam-gu, Seoul 06273, Korea. E-mail : mcpark@yuhs.ac

Copyright (c) 2020 by The Korean College of Rheumatology. All rights reserved.

This is an Open Access article, which permits unrestricted non-commerical use, distribution, and reproduction in any medium, provided the original work is properly cited. 
two years, and smaller number of syndesmophytes than patients without AAU with a hazard ratio of 0.21 .

Uveitis is the most common extra-articular manifestation of axSpA, and it can occur in more than half of axSpA patients during the course of their disease [11]. Conflicting results with respect to an association between AAU and radiographic damage of SpA have been reported. Several cross-sectional studies failed to demonstrate any association between AAU and radiographic progression in patients with AS [12-14] and SpA [15], whereas another study reported that a history of AAU was independently associated with more severe radiographic damage in patients with AS [16]. In contrast to these previous observations, Kim, et al. reported that a history of AAU was the only independent variable indicating less severe mSASSS changes in their PS-matched axSpA patients and, interestingly, other variables that have been known to be associated with progression of spinal damage were not found to be significant [10]. Although the reason for this discrepancy is not fully understood, the retrospective design of the study, relatively small number of patients, differences in the AAU prevalence between patient populations, and the possibility of index event bias should be considered when interpreting their results.

PS matching analysis is increasingly being used in observational studies, especially in studies where random assignment is not feasible. PS matching analysis is also useful in observational studies where the effects of the variables or interventions of interest for clinically important questions are not strong and need to be estimated more precisely in cohorts with wide heterogeneity $[17,18]$. As axSpA includes a vast array of clinical manifestations and progress slowly over the years, the effect of certain clinical parameters on the disease course remain poorly identified. In this regard, the study by Kim et al. [10] can be meaningful. This report is the first to evaluate the impact of various clinical variables on mSASSS changes in Korean axSpA patients using PS matching analysis. In addition, their findings can provide valuable evidence for the association of AAU with radiographic progression of axSpA, although the causal relationship between these factors should be further elucidated.

\section{CONFLICT OF INTEREST}

No potential conflict of interest relevant to this article was reported.

\section{REFERENCES}

1. Ward MM, Deodhar A, Gensler LS, Dubreuil M, Yu D, Khan MA, et al. 2019 Update of the American College of Rheumatology/Spondylitis Association of America/Spondyloarthritis Research and treatment network recommendations for the treatment of ankylosing spondylitis and nonradiographic axial spondyloarthritis. Arthritis Rheumatol 2019;71:1599613.

2. Lories RJ, de Vlam K, Luyten FP. Are current available therapies disease-modifying in spondyloarthritis? Best Pract Res Clin Rheumatol 2010;24:625-35.

3. Braun J, van der Heijde D. Imaging and scoring in ankylosing spondylitis. Best Pract Res Clin Rheumatol 2002;16: 573-604.

4. Creemers MC, Franssen MJ, van't Hof MA, Gribnau FW, van de Putte LB, van Riel PL. Assessment of outcome in ankylosing spondylitis: an extended radiographic scoring system. Ann Rheum Dis 2005;64:127-9.

5. Dougados M, Sepriano A, Molto A, van Lunteren M, Ramiro $\mathrm{S}$, de Hooge $\mathrm{M}$, et al. Sacroiliac radiographic progression in recent onset axial spondyloarthritis: the 5-year data of the DESIR cohort. Ann Rheum Dis 2017;76:1823-8.

6. Poddubnyy D, Haibel H, Listing J, Märker-Hermann E, Zeidler $\mathrm{H}$, Braun J, et al. Baseline radiographic damage, elevated acute-phase reactant levels, and cigarette smoking status predict spinal radiographic progression in early axial spondylarthritis. Arthritis Rheum 2012;64:1388-98.

7. Baraliakos X, Listing J, von der Recke A, Braun J. The natural course of radiographic progression in ankylosing spondylitis--evidence for major individual variations in a large proportion of patients. J Rheumatol 2009;36:997-1002.

8. van Tubergen A, Ramiro S, van der Heijde D, Dougados M, Mielants H, Landewé R. Development of new syndesmophytes and bridges in ankylosing spondylitis and their predictors: a longitudinal study. Ann Rheum Dis 2012;71: 518-23.

9. Ramiro S, Stolwijk C, van Tubergen A, van der Heijde D, Dougados M, van den Bosch F, et al. Evolution of radiographic damage in ankylosing spondylitis: a 12 year prospective follow-up of the OASIS study. Ann Rheum Dis 2015;74:52-9.

10. Kim KJ, Joo YB, Park YJ, Park KS. Association of uveitis with radiographic progression in patients with axial spondyloarthritis: a propensity score matching analysis. J Rheum Dis 2019;26:248-56.

11. Stolwijk C, Essers I, van Tubergen A, Boonen A, Bazelier MT, De Bruin ML, et al. The epidemiology of extra-articular manifestations in ankylosing spondylitis: a populationbased matched cohort study. Ann Rheum Dis 2015;74: 1373-8.

12. Chen HA, Chen CH, Liao HT, Lin YJ, Chen PC, Chen WS, et al. Factors associated with radiographic spinal involvement and hip involvement in ankylosing spondylitis. Semin Arthritis Rheum 2011;40:552-8.

13. Essers I, Ramiro S, Stolwijk C, Blaauw M, Landewé R, van der Heijde D, et al. Do extra-articular manifestations influence outcome in ankylosing spondylitis? 12-year results from OASIS. Clin Exp Rheumatol 2016;34:214-21.

14. Deminger A, Klingberg E, Geijer M, Göthlin J, Hedberg M, 
Rehnberg E, et al. A five-year prospective study of spinal radiographic progression and its predictors in men and women with ankylosing spondylitis. Arthritis Res Ther 2018; 20:162.

15. Gehlen M, Regis KC, Skare TL. Demographic, clinical, laboratory and treatment characteristics of spondyloarthritis patients with and without acute anterior uveitis. Sao Paulo Med J 2012;130:141-4.

16. Doran MF, Brophy S, MacKay K, Taylor G, Calin A. Predictors of longterm outcome in ankylosing spondylitis. J Rheumatol
2003;30:316-20.

17. Yao XI, Wang X, Speicher PJ, Hwang ES, Cheng P, Harpole $\mathrm{DH}$, et al. Reporting and guidelines in propensity score analysis: a systematic review of cancer and cancer surgical studies. J Natl Cancer Inst 2017;109:djw323.

18. Johnson SR, Tomlinson GA, Hawker GA, Granton JT, Feldman BM. Propensity score methods for bias reduction in observational studies of treatment effect. Rheum Dis Clin North Am 2018;44:203-13. 